\title{
EXPLORING SELF-REFLECTION PRACTICE AS A MEANS TO SELF-DEVELOPMENT FOR PROSPECTIVE TEACHER OF ELEMENTARY SCHOOL EDUCATION STUDY PROGRAM
}

\author{
Diah Yovita Suryarini ${ }^{1}$, Reza Syehma Bahtiar ${ }^{2}$ \\ ${ }^{1}$ Universitas Wijaya Kusuma Surabaya \\ ${ }^{2}$ Universitas Wijaya Kusuma Surabaya \\ ${ }^{1}$ dyovie24@gmail.com ${ }^{2}$ syehma fbs@uwks.ac.id
}

\begin{abstract}
This study aimed to investigate the self-reflection practice of prospective teacher of elementary education for their sense of self-development. This study will be guided by qualitative descriptive approach with phenomenology hermeneutics to investigate prospective teacher's feeling in their written text. Accordingly the text would be analyzed using rhetorical analysis. The data of this study were collected from six written self-reflection that has correct composition as reflection from six prospective teacher that has taken implementation of thematic based learning class. The data of this study were analyzed based on its rhetorical expression with the consideration of the three stages of reflection process. The result of this study revealed that written self-reflections of prospective teacher mostly follow the same flow of reflection and has the sense of self-development in terms of their new perspective on the matter under consideration. Their new persepective usually in terms of conclusion or self-encouragement on the matter under consideration. The implication of this study was Result of this study may encourage the practice of reflection or self-reflection for prospective teacher so that it can be practiced and implemented more to the prospective teacher for their own personal and professional development.
\end{abstract}

Keywords: self-reflection, self-development, prospective teacher of elementary school teacher

\begin{abstract}
Abstrak
Penelitian ini bertujuan untuk mengetahui praktik refleksi diri calon guru pendidikan dasar untuk pengembangan diri. Penelitian ini akan dipandu dengan pendekatan deskriptif kualitatif dengan hermeneutika fenomenologi untuk mengetahui perasaan calon guru dalam teks tertulisnya. Teks tersebut akan dianalisis dengan menggunakan analisis retoris. Data penelitian ini dikumpulkan dari enam refleksi diri tertulis yang memiliki komposisi yang benar sebagai refleksi dari enam calon guru yang telah melaksanakan pembelajaran berbasis tematik. Data penelitian ini dianalisis berdasarkan ekspresi retorisnya dengan pertimbangan tiga tahap proses refleksi. Hasil penelitian ini mengungkapkan bahwa refleksi diri tertulis calon guru sebagian besar mengikuti alur refleksi yang sama dan memiliki sense of development self-development. dalam hal perspektif baru mereka tentang masalah yang sedang dipertimbangkan. Persepektif baru mereka biasanya berupa kesimpulan atau dorongan diri sendiri atas masalah yang sedang dipertimbangkan. Implikasi dari penelitian ini adalah Hasil penelitian ini dapat mendorong praktik refleksi atau refleksi diri bagi calon guru sehingga dapat dipraktekkan dan diimplementasikan lebih kepada calon guru untuk pengembangan pribadi dan profesionalnya..
\end{abstract}

Kata Kunci: refleksi diri, pengembangan diri, mahasiswa PGSD

\section{INTRODUCTION}

Teacher is considered as a great asset in education; accordingly, as a teacher she/he needs to continuously develop her/himself to be a better and effective teacher. Developing themselves personally and professionally for teacher is essential, moreover if it is done in earlier stage, when they were still as prospective teacher. Prospective teacher needs to be 
introduced about reflective learning in order for them to be able to reflect from their own activity, their own action or their own experience, to be able to learn from it. Prospective teacher should realize that reflecting from the past experience whether in their learning or teaching practices can help them to improve skill, competence and even support for their confidence as part of their self-development.

Reflection in teacher education is crucial as it is connects well with learning in that learners use reflection to exercise their mind and to evaluate their learning experience. (Kuswandono, 2012). Reflection is beneficial for teacher and prospective teacher as well with the same mechanism. Reflection in educational field mostly related to the teacher practice in the classroom. Engaging in the reflection, teacher and prospective teacher can deal with uncertainty and unexpected situation in the classroom therefore they can have self-awareness of their current belief, attitude. They can develop new perspective and new ways in looking on their own action, and their own behaviour (Çimer et al., 2013). Whereas, reflection or reflective practice should be introduced or adapted in the education program classroom as part of the prospective teacher learning through experience during the class so that they may familiar with the practice for their own learning. Reflective practice is understood as the process of learning through and from experience to obtain new perception of self and practice (Finlay, 2008).

Prospective teacher is in important stage for them to understand that reflection is crucial part in improving their teaching practice based on their experience in class. Moreover, the prospective teacher of elementary education needs more confidence and competence in every classroom performance since they should bear bigger challenge than any other prospective teacher of any teacher education study program because they should master almost all elementary subjects.

Prospective teacher of elementary education, in particular, face different challenges in relation to teaching instruction as well as teaching practice. The challenge is corresponding to the Indonesian Curriculum that uses Curriculum 2013 or K-13 in which, the instruction that is used is based on thematic-based learning. By definition, thematic-based learning approach involves several subjects in a theme to give meaningful experience to students (Wardani et al., 2019) The shifting of the instructional strategy from fragmented educational unit-based learning to thematic-based learning has required elementary school teacher to be able to give thematic-based learning instruction. Basically, thematic-based learning is implemented for all level of school, from elementary school, middle school and high school, however, the use of thematic-based learning is very visible in the elementary school. Therefore, prospective teacher 
from elementary education are highly required to master the thematic-based learning instruction compare to prospective teacher of other teacher education study program. The prospective teacher of other study program usually only have to master one subject while prospective teacher of elementary education should master all the subject such as natural science, social science, mathematics, civic education, Bahasa, cultural arts and crafts and should be able to combine those several subject into one theme (Samsudin et al., 2019).

Based on the researcher's observation as a lecturer in Elementary education study program, the different characteristic of learning subjects between elementary education study program from another education study program, therefore prospective teacher of elementary education face bigger challenge. The curriculum of elementary education study program must adjust to the Indonesia National Curriculum which is Curriculum 2013, Accordingly, the elementary education study program provides subjects that intend to deepen the prospective teacher's knowledge on thematic based learning. One of the subjects is implementation of thematic-based learning. Specifically the implementation of thematic-based learning subject offers comprehensive learning in which the prospective teacher of elementary education not only should understand the theory but also they should be able to implement it in the teaching simulation in the class with their fellow classmates as the students. The class session would be divided into two session: presentation and simulation. Both of the session will have feedback from lecturer and fellow classmates that were given in written and in verbal. Since this subject implements small teaching simulation in which the prospective teacher was required to try to implement thematic based learning in the classroom with their friends as their students. Therefore, the simulation part usually made prospective teacher nervous and afraid, however, they had to do it as part of the lesson. During the class session, researchers, that is also happened to be the lecturer, in the beginning wanted to understand the prospective teacher' feelings about the learning in the implementation of thematic based class. Accordingly, to capture the prospective teacher's feeling, a reflective practice was implemented in the end of the class. There would be beneficial for the prospective teacher as well since they can reflect from their own learning, evaluate their learning and their teaching simulation through self-reflection. Moreover, based on the regulation of Indonesia Minister of National Education and Culture no 16:2007, it stated verbatim that the teacher should do reflection and it becomes one of the core competences of being teacher. It is also stated by (Boud et al., 1985) that reflection is a vital element in any form of learning and that teachers and trainers need to consider how they can incorporate some form of reflection in their courses and that inspired the study to assign 
reflective practice for the prospective teacher. Therefore, the implementation of self-reflection may appropriate for prospective teacher. Self-reflection is believed can help teacher to improve their teaching practice by look back their activities in the past, learned from them and make appropriate action to improve it.

Reflective practice has attracted interest many researchers. The researchers such as (Atkins \& Murphy, 1993; Finlay, 2008; Jay \& Johnson, 2002) interested in reflective learning concept. They conduct a literature study to discuss about the concept of reflective learning. While (Christie \& Kirkwood, 2006; Kayapinar, 2016) more interested in developing new framework or model for reflective practice or reflective learning. Reflective practice interest researcher to explore its process from three distinct area of data and resulted in six stages of reflective practice process (Boyd \& Fales, 1983). Furthermore, (Hobbs, 2007), interested in discussing the problematic nature that may come along with the reflective practice.

Some researchers also have been conducted research related to the self-reflection with several other focus. Mostly the focus was placed on the self-reflection that related to the academic performance in which the result of the study showed that self-reflection was able to give positive influence on student's academic performance or academic mindset (Lew \& Schmidt, 2011; Peck, 2019; Williams, 2015), while the other placed focus on self-reflection to improve professional development of professional teacher (Bautista \& Oretga-Ruiz, 2015; Bubnys, 2019; Çimer et al., 2013; Mathew et al., 2017; Philipsen et al., 2019). Some researchers also mention the reflection give benefit to students in terms of improving students critical thinking (Veine et al., 2019; Xhaferi \& Xhaferi, 2017). However it is just few researches that focus on self-reflection related to the prospective teacher self-development (Frick et al., 2010; Kuswandono, 2012). Accordingly, this current study has objectives to investigate the self reflection of prospective teacher of elementary education program to their sense of selfdevelopment. Furthermore, since this current study investigated the self-reflection that more likely has related to the prospective teacher's feeling accordingly, the researcher used phenomenology hermeneutics to help analysed the feeling that has put on the written self reflection by the prospective teacher. Related to that, the analysis also used rhetorical analysis in which it is less likely to be used in reflective practice research before.

\section{METHOD}

This study used qualitative approach, since this study wanted to reveals and describe the behavior and perception of prospective teacher about self-reflection, with 
phenomenological hermeneutics to investigate prospective teachers' feeling in their written text of self-reflection and interpret the phenomenon that may be found. Accordingly, the written text self-reflection would be analyzed using rhetorical analysis. Rhetoric refers to the writing or reporting style of someone's work. The data of this study were collected from six written self-reflection that has correct composition as reflection from six prospective teacher of elementary education from fifth semester that had taken implementation of thematic based learning class. The correct composition here refers to the written text that mentioned reflection or some of the thinking that the prospective teacher have been through while carrying out a particular practical activity. In other words, the written text is not only the description of activities but included the feeling. The instrument for this study was the researchers themselves.

The data of this study were collected in the end of the semester after researchers gave explanation in the beginning of second half of the semester. To obtain the data that could be analyzed, the researchers did as follows: (1) In the beginning of the course subject class, the researchers informed the prospective teacher to pay attention to the whole activity and experience in the class. (2) Informed the class that in the end of the semester, prospective teachers were asked to submit their written self-reflection based on their activity, experience, things that they have learned, things that they do, and the classmates' reactions or opinions to their fellow classmates during presentation and teaching simulation and their opinion or feelings regarding the activities in the during the lesson. (3) The written self-reflection that has been submitted would be analyzed and described. The prospective teacher reflected on experiences gained during the meetings and described the detail as much as possible.

As it is mention before, this study is to investigate the self-reflection practice to prospective teacher self-development, accordingly, the data analysis technique consists several steps, as follows: (1) The researchers obtain data from the prospective teacher in the form of written self-reflection. (2) Adopting the phenomenology hermeneutics method, by analyzing the text by phase, moving from the whole to parts and back, and from understanding to explanation and back and considering the writer feelings. This method also needs understanding of rhetoric. (3) Identify the possible rhetoric that describe the prospective teacher' perception. This perception will be based on three stages of reflection process as explained by (Atkins \& Murphy, 1993): (a) The first stage "is triggered by an awareness of uncomfortable feelings and thoughts," (b) which is followed by "a critical analysis of feelings and knowledge," and then (c) the development of a "new perspective" on the situation. (4) Describe and discuss the result with the underlying theories and answer the research question. 


\section{RESULTS AND DISCUSSION}

\section{Result}

Reflection according to Dewey (1938 as cited in Zahid \& Khanam, 2019) is the performance of an individual where only one actively and consistently involves in contemplation related experience and practice to make it more meaningful and successful. Accordingly, this study wanted to find out how the prospective teacher of elementary school teacher do self-reflection. In this case the self-reflection regarding their experience in taking the implementation of thematic based learning and their awareness for their self-development. As it is mention before, (Kenyon, 2017) stated that teacher's feeling is understood as the ways in which teacher's experience certain moments and live through particular phenomena.

Accordingly, phenomenological hermeneutics has become the basis approach for examining the prospective teacher's awareness in self-development through their written selfreflection. Phenomenological hermeneutics concerns with the rhetorical expression for understanding teacher feelings from their written self-reflection, accordingly it may showed the flows of prospective teacher feelings that eventually may be able to raised their awareness in their self-development. The result of the analysis on the prospective teacher's written selfreflection can be seen and interpreted as follows:

\section{Rhetorical expression Prospective teacher 1 (SDN)}

"Awalnya saya merasa takut karena saya merasa belum siap dengan mata kuliah tersebut" (At the beginning I was afraid because I was not ready to take this subject). Stage 1

“Awal presentasi memang saya ragu untuk menyajikan hasil kerja kelompok saya karena sedikit penjelasan materi yang saya temukan saat itu" (In the beginning of presentation, I had doubt in presenting my group work because the limited explanation about that subject matter that I have found). Stage 1

"Dari itu saya mengerti pada saat mencantumkan materi tidak hanya berpedoman dengan buku dan internet saja tapi harus berpedoman pada referensi-referensi lainnya”. (Therefore, 
I understand that when I put the material in the presentation, I am not only taking from book or internet but also other reference that necessary). Stage 2

"Pada saat teman saya simulasi pertama, saya terus memperhatikan bagaimana cara menyampaikan materi pembelajaran di kelas dan juga memperhatikan saran dan komentar dari dosen dan teman saya..." (When my friend started to do the first simulation, I continuously pay attention to how they deliver the material in the classroom and also, I paid attention the comment and suggestion from my lecturer and friend.) Stage 2

"Dari simulasi tersebut saya mengerti bahwa mengajar tidak hanya siap mental saja, suara keras saja, bisa ngomong banyak, tetapi harus menyiapkan materi, menyiapkan semuanya mulai dari media, model, dll yang harus disesuaikan dengan Rencana Pelaksanaan Pembelajaran (RPP) yang sudah dibuat..... Maka dari itu butuh melatih untuk menjadi seorang guru yang baik atau professional bagi siswa. Dan guru harus mampu memberikan berbagai pengetahuan atau ilmu bagi siswanya" (From the simulation I understand that teaching is not only mentally prepared, loud voice, able say a lot, but must prepare material, prepare everything from the media, models, etc. which must be adjusted to the Learning Implementation Plan that has been made... Therefore, it is necessary to practice to become a good or professional teacher for their students. Moreover, teacher must be able to provide various knowledge for their students). Stage 3

"Pada saat simulasi, dari situ saya mengetahui seberapa bisa saya menyampaikan pembelajaran kepada peserta didik dan kekurangan yang saya lakukan pada saat simulasi tersebut dapat dijadikan sebagai pelajaran selanjutnya untuk diperbaiki". (At the time of the simulation, from there I know how much I can convey learning to students and the shortcomings that I did during the simulation can be used as further lessons to be corrected.) Stage 3

The prospective teacher 1 (SDN) started to reflect her feelings on her written selfreflection by describing the lesson in which it was about thematic based learning. Based on the expression that was found in her written self-reflection, she straightforwardly mentioned that in the beginning she was afraid because she was not ready to take the subject, maybe because this subject required student to have small teaching simulation in the classroom. She also 
mentioned that in the middle of the lesson, she had to present a material related to implementation of thematic based learning, she also mentioned that she doubted her ability in this lesson especially when she should make presentation that in the end turned out unsatisfying. However, from her reflection that in making presentation more comprehensive, she should refer to more references. In this state she was able to reflect from her actions that were not quite right in the sense of making presentation and also, she was able to have selfencouragement to do better for next time. Furthermore, she also mentioned that during the implementation of thematic based learning done by her friends, she aware that she had to pay attention to it intensely. From her observation and her practice, she may reflect that to become a good teacher is not enough only by mentally prepared and so on but also a good preparation that adjusted to the learning implementation plan. In the end of her self-reflection, she concluded her feeling towards the lesson.

Based on the result, it can be said that the prospective teacher during the lesson, whether in the presentation part or teaching simulation part, she can express her feeling that she was afraid at the beginning, but by observing and practicing the thematic based learning teaching simulation as part of the lesson, she built awareness that she should take appropriate action and learn more to be able to become better future teacher. Accordingly, it showed that she had sense of self-development that can be seen in their self-reflection writing.

\section{Rhetorical expression Prospective teacher 2 (FMP)}

“... karena kelompok saya maju paling terakhir, saya agak meremehkan tugas tersebut.... Setelah H-7 saya jadi khawatir sendiri akan tugas tersebut....Pada saat presentasi ternyata materi kelompok saya dinyatakan kurang lengkap.. saya merasa bahwa kedepannya saya tidak boleh meremehkan tugas yang diberikan" (... since my group had the last turn, I somewhat underestimated the task.... After D-7 I became worried myself about the assignment .... At the time of presentation it turned out that my group material was declared incomplete ..I feel that in the future I should not underestimate the assignment given). Stage 1

“Apalagi ketika ingat kejadian presentasi yang kurang serta kelemahan saya yakni gugup bicara di sepan banyak orang. Sehari sebelum simulasi saya merasa kurang bersemangat, takut, gugup dan perasaan negative lainnya campur jadi satu." (Especially when I remember that my presentation that was declared incomplete and my weakness which was, I felt nervous 
about speaking in front of many people. The day before simulation I felt lacklustre, scared, nervous and other mixed negative feeling). Stage 1

"Saat hari simulasi tiba, saya menekankan pada diri sendiri untuk harus bisa. Simulasi seperti ini sudah sering dilakukan di mata kuliah lain. Jadi bukan hal baru lagi untuk saya...Sudah selesai simulasi... teman-teman menanggapi penampilan saya, ada kritik dan saran, saya pun menerimanya sebagai bahan evaluasi saya pada simulasi lainnya. Namun diatara komentar itu ada satu komentar yang membuat saya lega. Intinya teman saya mengomnetari pembelajaran saya yang benar-benar tematik, yakni peralihan dari mata pelajaran satu ke mata pelajaran lain tidak tampak. Itu benar-benar mengembalikan sisi percaya diri saya dan mermbuat saya tidak meragukan kemampuan diri saya sendiri." (When the simulation day arrived, I assured myself to have to be able to do it. Simulations like this have often been done in other courses. So, it's not new to me anymore... When the simulation finished... my friends responded to my performance, there were criticisms and suggestions, I also accepted them as my evaluation for other simulations. But among those comments there was one comment that made me relieved. In essence, my friend commented on my learning which was really thematic, that is, the transition from one subject to another was not visible. It really brought back my confident side and made me not doubt my own abilities). Stage 2 and stage 3

The writing sample of self-reflection written by prospective teacher 2 (FMP) showed that basically through written self-reflection, she can reflect that she had time to procrastinate in doing her task with her group member, but then she got worried when the presentation time got nearer. Based on her writing it feels that she regretted that she deliberately procrastinates in doing her task and the task was not going well either. In the beginning she felt regretful because her procrastination in doing her presentation and end up to have an incomplete presentation, however, she had learned that she should not belittle the task since she got the last material and had much time to do it. Accordingly, she also expressed her worry in doing simulation, she was afraid that she might make the mistake like she did in the presentation part. However, she also expressed that she can encourage herself to be able to do the task appropriately. She also expressed that she gained her self-confidence again in teaching because she got the good remark from her fellow classmates and lecturer about her performance in teaching simulations. 
Basically, the expressions that researchers found in the written self-reflection still inconclusive to be able to categorize as her awareness of self-development. However, her ability to understand that she had make a mistake by letting her procrastination in doing her task during the lesson and she was able to look back of her mistake made her have sense of self-development so that she will not do the same think in the future. Besides that, her selfencouragement in doing teaching simulation seemed to show her intention in self-development so that she can do better than she already had in presentation part. It showed that she learned from her first action that was it should be improve to get the better result.

\section{Rhetorical expression Prospective teacher 3 (NEP)}

“Jujur saja saya sudah sering presentasi atau simulasi di depan kelas. Akan tetapi tetap saja ada perasaan deg-degan/grogi yang muncul pada saat saya di depan kelas.” (Honestly, I often have presentations or simulations in front of the class. However, there is still a feeling of nervousness that appears when I am in front of the class). Stage 1

“... Awalnya saya bingung untuk perpindahan materi satu ke materi lainnya agar nyambung saya harus bagaimana. Saya baca berkali kali buku siswa tersebut. Setiap hari saya membuka buku siswa untuk memantapkan materi yang akan saya ajarkan.” ( ... At first I was confused about connecting one material to another accordingly what should I do to connect. I read the student book many times. Every day I open student books to strengthen the material I will teach). Stage 1 and stage 2

"Saya pikir cukup dengan memantau di depan dan sesekali ke bangku siswa ternyata kurang dan juga pada saat ada komentar memberi contoh kehidupan sehari-hari saya juga baru sadar kenapa saya tidak terpikirkan untuk memberi contoh dikehidupan sehari-hari lalu saya tayangkan di LCD. Mungkin saya terlalu focus dengan penataan materi yang akan saya sampaikan. " (I thought it was enough to monitor in front of the class and occasionally go to the student seats, it turned out that it was still lacking and also when there were comments about giving examples of daily life, I also just realized why I didn't think about giving examples in everyday life then I put it on the LCD. Maybe I am too focused on the arrangement of the material that I would convey to the audience or students). Stage 2 and stage 3 
"Saya sangat senang mendengar komentar tersebut, berarti saya sudah bisa dan saya harus bisa memperbaiki apa yang kurang pada saat simulasi." (I was glad to hear those comments, which means I was able and must be able to improve what is lacking at the time of teaching simulation.). Stage 3

The third prospective teacher (NEP) reflect on her experience in the class by looking back that in her presentation turn, she forgot to include the hard copy of the sample of Learning Implementation Plan (or LIP) so the lecturer and classmates can follow the explanation. However, she can make the presentation right immediately by displaying the sample of Learning Implementation Plan on the screen. She may be able to reflect from her presentation that she should prepare the material properly and need to be able to think of an immediate action to make her presentation right.

Furthermore, in her reflection about her teaching simulation, she, indeed, mention that she was confuse in making the subject material in thematic based in which she should consider how to shift the one subject to another in a smooth way in one theme. She reflected that she should learned the material thoroughly and repeatedly to make her teaching simulation near perfect. However, when she did the simulation, she got the suggestion regarding her simulation and she was able to learned that she needed to consider the improve her action in teaching and delivering material in the future. Accordingly, through her expression that can be found in her self-reflection, she made some reflection on her action during the lesson and also give though about that to be done in the future for her to be able to become a good teacher.

\section{Rhetorical expression Prospective teacher 4 (INF)}

"Saya juga bereksplore diri lebih jauh tentang cara mengajar langsung di kelas." (I also explored myself further about how to teach directly in class). Stage 2

“...saya mulai memahami ap aitu arti pembelajaran tematik dan langsung bisa mempraktekkan di kelas...” (... I began to understand what thematic learning meant and could immediately put it into practice in class...). Stage 2

Di mata kuliah ini juga memberikan motivasi belajar yang lebih sehingga dapat berbicara di depan umum dengan lancar melalui praktik simulasi mengajar di kelas hal ini sungguh sangat membantu untuk calon guru”. (In this subject, it also provides more motivation to 
learn so that I can speak in public fluently through the practice of teaching simulations in the classroom, this is really very helpful for prospective teacher.). Stage 2

"Saya merasakan suasana jadi guru secara langsung dan saya juga sedikit demi sedikit memahami bagaimana menjadi guru yang professional." (I feel the atmosphere of being a teacher directly and I also gradually understand how to be a professional teacher.). Stage 3

"Sesi saran dan kritik... disitulah saya mulai belajar menjadi guru yang inovatif dan kreatif yang bisa membuat pembelajaran tidak berkesan monoton dan membosankan akan tetapi juga menggunakan media dan metode yang bisa menarik gairah belajar siswa."(Suggestion and criticism session... that's where I started to learn to be an innovative and creative teacher who could make learning less monotonous and boring but also used media and methods that could attract students' passion for learning.) Stage 3

“... sangat disiplin hal itu yang membuat saya tertarik dengan sifatnya yang mencerminkan guru yang kompeten. Dari sifat disiplin itu saya harus bisa mengikuti jejak kedisiplinannya." (... So disciplined that it makes me interested in her character which reflects a competent teacher. From the nature of that discipline, I must be able to follow in the footsteps of her discipline). Stage 3

"Saya senang dan bertambah semnagat saat proses pembelajaran berlansung karena menurut saya dosen pengampu kali ini sangat disiplin termasuk untuk masalah nilai." (I am happy and more enthusiastic when the learning process took place because in my opinion the lecturer who teaches this time is very disciplined, including for the scoring grade.) Stage 3

From the expressions that were found in the written self-reflection made by the prospective teacher 4 (INA), it can be seen that when he looked back to his experience in the classroom, he got something that may be improve himself. He mentioned that he can explore himself further in this class because he can experience teaching directly in the class, even though it is only in front of his classmates, he can speak in public and smoothly delivered the teaching simulation.

Especially in the teaching simulation part, he mentioned that through his experience in teaching simulation along with feedbacks from classmates and lecturer, he can reflect his own 
teaching and was able to conclude that he may learn to be able to become an innovative and creative teacher and also able to make the lesson more memorable for his future students. Moreover, he also reflected on his experience during the lesson about the disciplinary act done by the lecturer, accordingly he wanted to be able to be more discipline in the future, not only for himself but also for his future students. Based on his expression, he was able to reflect from his experience and mentioned it that he would be improving himself in the future therefore it showed his intention to have self-development.

\section{Rhetorical expression Prospective teacher 5 (RAOG)}

"Saat diberikan tugas maju individu menerapkan RPP tematik saya tidak yakin bisa karena menurut saya membuat RPP itu sendiri sudah agak rumit apalagi menerapkannya di depan dengan mensimulasikan bagaikan sudah mengajar anak-anak SD sesungguhnya. Tapi disitulah tantangannya, kalau tidak berani maju sampai kapanpun kita siap untuk terjun ke sekolah nanti terlebih saat PPL. Pasti akan lebih sulit menghadapi sikap dan karakter anakanak SD yang sesunggughnya." (When I was given the individuals task to implement thematic lesson plans, I was not sure I could because in my opinion making the lesson plans itself was a bit complicated, let alone implementing it up front by simulating as if they had actually taught elementary school children. But that is the challenge, if we don't dare to go forward whenever we are ready to go to school, especially during PPL. It would have been more difficult to deal with the true attitudes and character of elementary school children.) Stage 1

"Saat saya maju saya msih merasa bahwa belum menampilkan yang maksimal karena masih terkesan belum mengaitkan pemebelajaran satu dengan yang lainnya" (When my turn to perform the simulation task, I still feel that I haven't performed optimally because I still seem to have not linked the subject learning with one to another.) Stage 1

"Saya masih berpikir bahwa saya harus terus mengembangkan diri saya dalam pembelajaran tematik terpadu. Karena saat ini saya baru praktek di depan teman-teman saya sendiri masih belum maksimal apalagi saat saya tampil di depan murid-murid SD yang sesungguhnya. Pasti lebih menantang...”( I still think that I have to continue to develop myself in integrated thematic learning. Because at this time I just practiced in front of my own friends, it was still not optimal, especially when I performed in front of real elementary school students. Definitely more challenging ...) Stage 2 and stage 3 
In this written self-reflection done by the fifth prospective teacher (RAOG), she did not give much expression in her written self-reflection about her presentation task. It might be because she has done it multiple time therefore, presentation task was not matter to her. However, when it comes to teaching simulation task, she mentioned that she was doubting herself to be able to do teaching simulation appropriately. Yet, she encourages herself that it was part of the challenge that she must overcome to be able to become a real teacher after she graduated.

Through her experience in the teaching simulation, she reflected that she has not done it maximally since she was not able to connect the lesson from one subject to another subject in which it is the essence of thematic based learning for elementary school. However, she also mentioned that she needed to think that she had to develop herself in thematic based learning for her real future students considering the real elementary school students more challenging because she has to deal with different type and characters of the elementary students.

Through her self-reflection writing, it seemed that she had shortcoming in doing thematic based learning, therefore she had intention in develop herself in teaching thematic based learning and deal with the real elementary school student by showing her expression in giving herself self-encouragement to be able to be a good teacher.

\section{Rhetorical expression Prospective teacher 6 (MKR)}

MKR “Dalam inti pembelajaran ini saya merasa waktu yang dibutuhkan cukup banyak tidak cukup hanya $1 x$ pertemuan. Dibutuhkan $2 x$-3x pertemuan agar pembelajaran menjadi maksimal...." (At the core of this lesson, I felt that the time needed is quite a lot, not enough for only one meeting. It takes 2x-3x meetings for maximum learning....) Stage 1 and Stage 3

\section{"Pada simulasi ini saya hanya memberikan materi di dalam kelas sehingga pembelajaran} yang dilakukan kurang bermakna tidak melihat obyek yang menjadi pokok bahasan." (In this simulation, I only provide material in class so that the learning is not meaningful without seeing the object in real). Stage 1 and stage 2

\section{“...terlebih untuk simulasi membuat saya lebih percaya diri sebagai calon guru dan juga} sebagai bekal untuk persiapan PPL.” (... especially for the simulation, it makes me more confident as a prospective teacher and also as a provision for PPL preparation.) Stage 3 
In this self-reflection, in the beginning the prospective teacher has reflected more on her teaching simulation. However, it is also showed that she was able to looked back in her teaching simulation and expressed it in her self-reflection writing. As it can be seen that she expressed that she understood that in the learning process it might need more meeting time than it should be done in the simulation, it should be learning in the real environment which means not only conducted in the classroom because her subject is related natural science therefore, she thought that it would be better if she could show the real object to the students.

In the last part of her written self-reflection, she reflected that during the class she can obtain necessary experience that can be used in teaching practicum, and by practicing the teaching simulation can help her to become professional teacher. It means that she can looked back on her experience during the lesson, and she intended to be able to perform better in the future by evaluating her teaching simulation directly and expressed it in her written selfreflection.

\section{Discussion}

An analysis of the rhetorical expression on each written self-reflection of prospective teacher under study has evidenced that the self-reflection written by prospective teacher of elementary school teacher showed student-teacher awareness on their own self-development. It can be seen in their expression which showed that they did contemplating their action by recalling what they have been done during the lesson in one semester, considered that the action appropriate or inappropriate (good or bad), therefore they can assess that this action or experience needed to improve or need to be appraise and still improve it to a better action. This action of self-reflection in this study was in accordance of the purpose of reflection according to (Kuswandono, 2012) in which stated that reflective practice is essential as a lens to look into educational practices critically. The purpose of reflection is to understand experience not merely s common thinker but to be a pedagogical thinker who is sensitive to address the needs of the learner. Accordingly, self reflection practice that has been done by the prospective teacher may lead to personal and professional development, so that it become comprehensive self-development.

The result of the study showed that prospective teacher of elementary school teacher has expressed their awareness on their self-development in their written self-reflection. Their practice in self-reflection basically has contribute to their awareness of their activity that has 
been done during the lesson whether the action is considered satisfying or unsatisfying, good or bad meaning and then gave deep thought to the personal growth (self-development) that may also lead to the professional growth. Basically, Atkins and Murphy (1993) identifies three stages of the reflective process: (a) The first stage "is triggered by an awareness of uncomfortable feelings and thoughts," (b) which is followed by "a critical analysis of feelings and knowledge," and then (c) the development of a "new perspective" on the situation. This can be seen in their written moves that flows from their concern about their knowledge of the lesson, their concern about the teaching simulation, yet, they sometimes can give themselves self-encouragement or make conclusion by giving new perspective on the situation. This flow can be seen exist on almost prospective teacher under study, but it can be seen obviously in prospective teacher $1(\mathrm{SDN})$.

\section{CONCLUSION}

The result of the study that was obtained from self-reflection written by prospective teacher of elementary education revealed that through the self-reflection, prospective teacher can reflect their own learning and built their new perspective for their learning. Their written self-reflection expressed their concern in the beginning and gradually defined what is good action or bad action. In the end, usually they make conclusion from that action in several ways, may be by self-encouragement, finding new perspective so that they may develop themselves to be a better prospective teacher and also to become a good teacher in the future with the consideration that through reflection, prospective teacher can have personal and professional development.

The result of this study may contribute: first, theoretically that self-reflection may raise awareness for self-development since the prospective teacher can look back on their own learning. Secondly that self-reflection was able to analyze using phenomenology hermeneustic using rhetorical as tools of analysis in which it may seem less likely to be used before. The novelty of this reseach laid on the sense that this study analyzed through prospective teacher's feeling that showed in the written self-reflective. However this research still have limitation, since the sample of written self-reflection was limited only six text, therefore it was not yet able to provide a comprehensive picture. For future research, it would be better if the future research have more written text of self-reflection, the self-reflection study may conduct to microteaching class so that the self reflection is able to be more comprehensive, self reflection 
as prospective teacher and as teacher iin micriteaching class, The implication of this study is that the practice of self-reflection is more likely to be done often, maybe included as assignment to the student as a prospective teacher so that they familiar and understand the benefit of making reflection.

\section{ACKNOWLEDGMENTS}

This work was supported by LPPM Universitas Wijaya Kusuma Surabaya

\section{REFERENCES}

Atkins, S., \& Murphy, K. (1993). Reflection: a review of the literature. Journal of Advanced Nursing, 18(8), 1188-1192. https://doi.org/10.1046/j.1365-2648.1993.18081188.x

Bautista, A., \& Oretga-Ruiz, R. (2015). Teacher Professional Development: International Perspectives and Approaches. Psychology, Society, \& Education, 7(3), 240-251. https://doi.org/10.25115/psye.v7i3.1020

Boud, D., Keogh, R., \& Walker, D. (Reds). (1985). Reflection: Turning Experience into Learning. RoutladgeFalmer Taylor and Francis Group. books.google.co.id/books?id=XuBEAQAAQBAJ\&printsec=frontcover\&dq=Promoting +reflection+in+learning:+a+model\&hl

Boyd, E. M., \& Fales, A. W. (1983). Reflective learning: Key to Learning from Experience. Journal of Humanistic Psychology, 23(2), 99-117. https://doi.org/10.1177/0022167883232011

Bubnys, R. (2019). A journey of self-reflection in students' perception of practice and roles in the profession. Sustainability (Switzerland), 11(194), 1-17. https://doi.org/10.3390/su11010194

Christie, D., \& Kirkwood, M. (2006). The new standards framework for Scottish teachers: facilitating or constraining reflective practice? Reflective Practice, 7(2), 265-276. https://doi.org/10.1080/14623940600688720

Çimer, A., Çimer, S. O., \& Vekli, G. S. (2013). How does Reflection Help Teachers to Become Effective Teachers? International J. Educational Research, 1(4), 133-149. https://www.academia.edu/10783045/How_does_Reflection_Help_Teachers_to_Becom e_Effective_Teachers

Finlay, L. (2008). Reflecting on reflective practice. In Practice -based Professional Learning Center (Number January). http://ncsce.net/wp-content/uploads/2016/10/Finlay-2008Reflecting-on-reflective-practice-PBPL-paper-52.pdf

Frick, L., Carl, A., \& Beets, P. (2010). Reflection as learning about the self in context: Mentoring as catalyst for reflective development in pre-service teachers. South African Journal of Education, 30(3), 421-437. https://doi.org/10.15700/saje.v30n3a363 
Hobbs, V. (2007). Faking it or hating it: can reflective practice be forced? Reflective Practice, 8(3), 405-417. https://doi.org/10.1080/14623940701425063

Jay, J. K., \& Johnson, K. L. (2002). Capturing complexity: A typology of reflective practice for teacher education. Teaching and Teacher Education, 18(1), 73-85. https://doi.org/10.1016/S0742-051X(01)00051-8

Kayapinar, U. (2016). A study on reflection in in-service teacher development: Introducing reflective practitioner development model. Kuram ve Uygulamada Egitim Bilimleri, 16(5), 1671-1691. https://doi.org/10.12738/estp.2016.5.0077

Kenyon, E. A. (2017). Lived experience and the ideologies of preservice social studies teachers. Teaching and Teacher Education, 61, 94-103. https://doi.org/10.1016/j.tate.2016.10.006

Kuswandono, P. (2012). Reflective Practices for Teacher Education. Language and Language Teaching Journal, 15(01), 149-162. https://doi.org/10.24071/11t.2012.150102

Lew, M. D. N., \& Schmidt, H. G. (2011). Self-reflection and academic performance: Is there a relationship? Advances in Health Sciences Education, 16(4), 529-545. https://doi.org/10.1007/s10459-011-9298-z

Mathew, P., Mathew, P., \& Peechattu, J. (2017). Reflective Practices: a Means To Teacher Development. Asia Pacific Journal of Contemporary Education and Communication Technology, ISSN(3), 2205-6181. https://apiar.org.au/wpcontent/uploads/2017/02/13_APJCECT_Feb_BRR798_EDU-126-131.pdf

Peck, K. (2019). The Influence Of Student Self-Reflection On Academic Mindset Change [Hamline University]. In School of Education Student Capstone Thesis and Dissertation 4467. https://digitalcommons.hamline.edu/hse_all/4467

Philipsen, B., Tondeur, J., Pynoo, B., Vanslambrouck, S., \& Zhu, C. (2019). Examining lived experiences in a professional development program for online teaching: A hermeneutic phenomenological approach. Australasian Journal of Educational Technology, 35(5), 46-59. https://doi.org/10.14742/ajet.4469

Samsudin, A., Kelana, J. B., \& Muftianti, A. (2019). Utilization of Internet-Based Learning Media in Enhancing Science Literacy Capabilities of Pgsd Students. PrimaryEdu Journal of Primary Education, 3(2), 91-96. https://doi.org/10.22460/pej.v3i2.1284

Veine, S., Anderson, M. K., Andersen, N. H., Espenes, T. C., Søyland, T. B., Wallin, P., \& Reams, J. (2019). Reflection as a core student learning activity in higher education Insights from nearly two decades of academic development. International Journal for Academic Development, 25(2), 147-161. https://doi.org/10.1080/1360144X.2019.1659797

Wardani, N. F. K., Sunardi, \& Suharno. (2019). Thematic Learning in Elementary School: Problems and Possibilities. Advances in Social Science, Education, and Humanities Research, 3rd International Conference on Learning Inovation and Quality Education (ICLIQE), 397(Icliqe 2019), 791-800. https://doi.org/10.2991/assehr.k.200129.099 
Williams, J. D. (2015). Why Kids Need to Be Bored: A Case Study of Self-Reflection and Academic Performance. RMLE Online, 29(5), 1-17. https://doi.org/10.1080/19404476.2006.11462028

Xhaferi, B., \& Xhaferi, G. (2017). Enhancing Learning Through Reflection- A Case Study of SEEU. SEEU Review, 12(1), 53-68. https://doi.org/10.1515/seeur-2017-0004

Zahid, M., \& Khanam, A. (2019). Effect of reflective teaching practices on the performance of prospective teachers. Turkish Online Journal of Educational Technology - TOJET, 18(1), 32-43. https://eric.ed.gov/?id=EJ1201647\#: :text 